\title{
New species and new reports in the Australian Graphidaceae
}

\author{
Alan W. Archer ${ }^{1}$ and John A. Elix ${ }^{2}$ \\ ${ }^{1}$ Royal Botanic Gardens, Mrs Macquaries Road, Sydney, NSW 2000, Australia \\ ${ }^{2}$ Chemistry Department, The Faculties, Australian National University, Canberra, ACT 0200, \\ Australia
}

\begin{abstract}
Four new species, Anomomorpha roseola, Fissurina praetermissa, Graphis eimeoensis and Graphis gloriosensis are reported from Australia. Diorygma hololeucum (Mont.) Kalb, Staiger \& Elix, Graphis atrofusca Müll.Arg., Graphis geraensis Redinger, Graphis illota Müll.Arg., Graphis macella Kremp., Graphis maritima (A.W.Archer) A.W.Archer, Graphis tenellula Vain., Phaeographis epruinosa (Redinger) Staiger and Platygramme platyloma (Müll.Arg.) M. Nakan. \& Kashiw. are reported for the first time from Australia. The lichen genus Anomomorpha is reported for the first time from Australia.
\end{abstract}

\section{Introduction}

A recent account of the lichen family Graphidaceae in Australia (Archer 2006) listed 127 species, including 8 species in the genus Diorygma, 10 species in Fissurina, 54 species in Graphis, 19 species in Phaeographis and 8 species in Platygramme. A recent examination of further specimens from BRI and CANB has found additional species, including four new species, viz; Anomomorpha roseola, Fissurina praetermissa, Graphis eimeoensis and Graphis gloriosensis together with six Graphis species not previously reported from Australia: Graphis atrofusca Müll.Arg., Graphis geraensis Redinger, Graphis illota Müll. Arg., Graphis macella Kremp., Graphis maritima (A.W.Archer) A.W.Archer and Graphis tenellula Vain. The genus Anomomorpha Nyl. is reported for the first time in Australia and Diorygma hololeucum (Mont.) Kalb, Staiger \& Elix, Phaeographis epruinosa (Redinger) Staiger and Platygramme platyloma (Müll.Arg.) M.Nakan. \& Kashiw. are also reported for the first time in Australia.

In the present work chemical constituents were identified by thin layer chromatography (Elix \& Ernst-Russell 1993), high performance liquid chromatography (Elix et al. 2003) and by comparison with authentic samples. 


\section{New species}

Anomomorpha roseola A.W.Archer \& Elix, sp. nov.

Fig. 1

Similis Anomomorpha sordida Staiger sed ascosporiis muriformibus et acidum virensicum et neotriconicum continens.

Type: Australia, New South Wales, Styx River State Forest, Softwood Road, 30³2'S, $152^{\circ} 25^{\prime} \mathrm{E}$, alt. c. $1500 \mathrm{~m}$, on bark of tree in rainforest, R.W. Rogers 10063, 8 Mar 1988; holotype: BRI 687089; isotype: BRI.

Thallus pale fawn to pale olive green, surface smooth and shiny, corticolous; apothecia lirelliform, sessile, scattered, linear to irregularly oval, lips open, margins inrolled, 1-2 mm long, 0.3-0.5 mm wide; exciple uncarbonised; epithecium pink, white pruinose; hymenium 80-120 $\mu \mathrm{m}$ tall, I-ve, inspersed; ascospores 8 per ascus, hyaline, 10-12 $\mu \mathrm{m}$ long, $6 \mu \mathrm{m}$ wide, initially 4-locular becoming muriform, 4 x 2-locular, I+ weak blue.

Chemistry: (hplc): neotricone (major), virensic acid (submajor), norperistictic acid (minor), norstictic acid (minor), salazinic acid (trace), protocetraric acid (trace).

Specimen examined: New South Wales: Northern Tablelands: Werrikimbe National Park, Beech Plateau, $80 \mathrm{~km}$ NW of Port Macquarie, $31^{\circ} 12^{\prime} \mathrm{S}, 152^{\circ} 19^{\prime} \mathrm{E}$, alt. $1000 \mathrm{~m}$, on semi-shaded upper Nothofagus trunk, H. Streimann 63984, 18 Jun 1999 (CANB).

Anomomorpha roseola is characterised by sessile, open lirellae, revealing a white pruinose, pink epithecium, an uncarbonised exciple, small muriform ascospores, an inspersed hymenium and the presence of neotricone and virensic acid. It is distinguished from A. subtorquens (Nyl.) Staiger by the larger ascospores (globular, 5-6 $\mu \mathrm{m}$ diam, in A. subtorquens) and the presence of virensic acid in addition to neotricone and norstictic acid. Graphina samoana Zahlbr. (Zahlbruckner 1908) has ascospores similar in size to those of $A$. roseola but that species lacks an inspersed hymenium ("non oleo" fide Zahlbr. loc. cit.) and contains norstictic acid as a major compound.

The genus Anomomorpha Nyl. (Nylander in Hue 1891) is one of several older genera in the family Graphidaceae which have recently been resurrected and revised (Staiger 2002). It is characterised by an uncarbonised exciple, an inspersed hymenium, small $(<15 \mu \mathrm{m}$ long) ascospores and the presence of norstictic acid \pm neotricone. The genus has been reported from the USA (Florida), Colombia, Brazil, Reunion, the Andaman Islands (Staiger 2002) and the Solomon Islands (Archer 2007); the new species described above represents the first report of the genus in Australia and the occurrence of virensic acid in the genus.

The presence of virensic acid as a significant lichen compound is compatible with the biosynthetic pathway to norstictic acid and neotricone. Oxidation of the 6-methyl group in virensic acid to an aldehyde and intramolecular cyclisation gives the corresponding hydroxylactone, norstictic acid, whereas partial oxidation of the 6-methyl group of virensic acid to a hydroxymethyl group followed by lactonisation, and oxidation of the 4-aldehyde group to a carboxylic acid gives neotricone.

Fissurina praetermissa A.W.Archer \& Elix, sp. nov.

Fig. 2

Similis Fissurina dumastii Fée sed saxicola et ascosporis muriformibus.

Type: Australia, New South Wales, North Coast, Conglomerate State Forest, Waihou Road, near Waihou, $30^{\circ} 06^{\prime} \mathrm{S}, 153^{\circ} 01^{\prime} \mathrm{E}$, alt. c. $400 \mathrm{~m}$, on semi-shaded sandstone rock. 


\section{A.W. Archer G 187, 19 Apr 1998; holotype: NSW 740892.}

Thallus pale olive green, surface smooth and shiny, corticolous; apothecia lirelline, inconspicuous, immersed, initially slit-like, finally opening to reveal a pale fawn epithecium with pale fawn margins, straight or curved, rarely branched, 0.5-1.5 mm long, 0.1-0.2 mm wide; epithecium epruinose; exciple uncarbonised, complete, pale orange-brown; hymenium 120-150 $\mu \mathrm{m}$ tall, not inspersed, I-ve; ascospores 8 per ascus, ellipsoid, hyaline, 12-16 $\mu \mathrm{m}$ long, 5-7 $\mu \mathrm{m}$ wide, 4-6 x 2-locular, I-ve.

Chemistry: no lichen compounds found.

The species is characterised by the inconspicuous, fissurine lirellae, the saxicolous habit, the small, muriform ascospores and the absence of lichen compounds. It is so far known only from the type specimen. The Fissurina dumastii group (Staiger 2002) contains 10 species of which five have spores which are 4-locular and thus distinct from $F$. praetermissa. Of the remaining species, four have larger muriform ascospores (15-35 $\mu \mathrm{m}$ long) and the somewhat similar F. nitidescens (Nyl.) Nyl. is corticolous and has ascospores reacting I+ violet. The recently described saxicolous Fissurina species, F. saxicola, from India (Makhija \& Adawadkar 2007) has 4-locular ascospores and contains stictic acid; this species is thus distinct from F. praetermissa.

Graphis eimeoensis A.W.Archer \& Elix, sp. nov.

Fig. 3

Sicut Graphis tenellula Vain. sed excipulo integro et ascosporis majoribus.

Type: Australia, Queensland: Eimeo Salt Marsh, $21^{\circ} 02^{\prime} S, 149^{\circ} 10^{\prime} E$, alt. sea-level, on Lumnitzera, G.N. Stevens s.n., 14 Aug 1976; holotype: BRI 689315.

Thallus off-white to pale fawn, surface smooth and dull, corticolous; apothecia lirelline, conspicuous, numerous, crowded, sessile, prominent, simple, straight or slightly curved, terminally acute, with thalline margin to top of the exciple, lips closed, sometimes becoming slightly open to reveal a white pruinose disc, $0.7-2.0 \mathrm{~mm}$ long, $0.2-0.3 \mathrm{~mm}$ wide; exciple completely carbonised; hymenium inspersed, I-ve; ascospores 8 per ascus, hyaline, elongate ellipsoid, 54-70 $\mu \mathrm{m}$ long, 9-10 $\mu \mathrm{m}$ wide, 14-16-locular.

Chemistry: norstictic acid

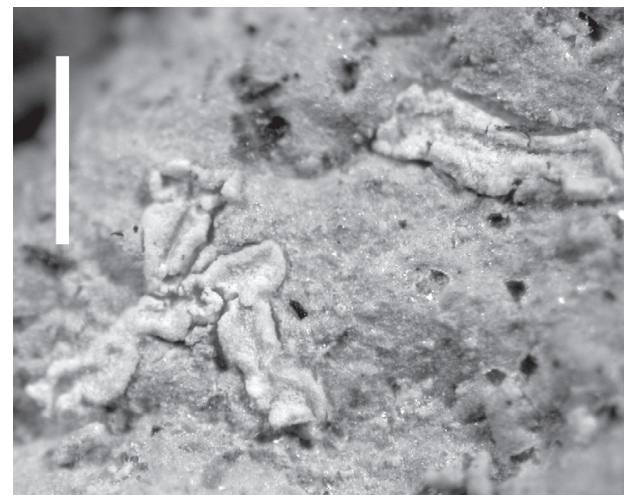

Fig. 1. Anomomorpha roseola, holotype. Scale bar $=1 \mathrm{~mm}$

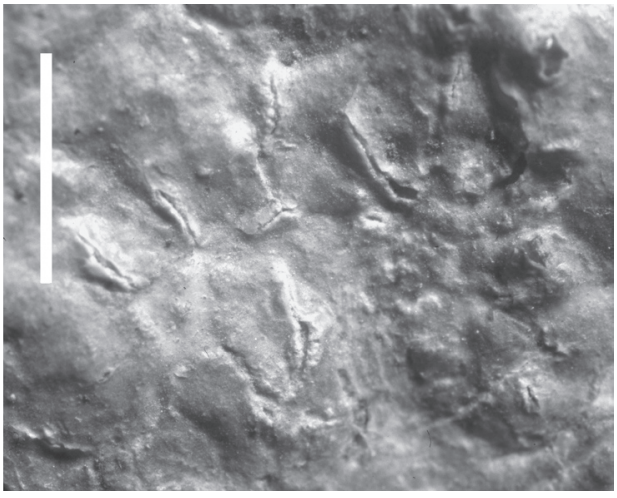

Fig. 2. Fissurina praetermissa, holotype. Scale bar $=1 \mathrm{~mm}$ 
The species is characterised by simple sessile, prominent lirellae, the completely carbonised exciple, inspersed hymenium and the presence of norstictic acid. It resembles the chemically similar Graphis tenellula Vain. but that species has smaller ascospores and a laterally carbonised exciple. The Australian species G. catherinae A.W.Archer has ascospores of a similar size to G. eimeoensis and an inspersed hymenium but lacks lichen compounds. The new species also resembles the chemically similar species G. lumbricina Vain. (Vainio 1899) but that species has larger ascospores, [75-120 $\mu \mathrm{m}$ long], has a striate exciple and the hymenium is not inspersed (Wirth \& Hale 1978). The new species is distinguished from G. centrifuga Räs. by the smaller ascospores in the latter species.

Graphis eimeoensis is known so far only from the type specimen; it occurs with Phaeographis ceratoides Vain. and Graphis streimannii A.W.Archer on mangroves at the type location.

Graphis gloriosensis A.W.Archer \& Elix, sp. nov.

Fig. 4

Sicut Graphis rustica Kremp. sed lirellis furcatis et hymenio insperso.

Type: Australia, Queensland: Highvale, by side of road to Mount Glorious, $27^{\circ} 23^{\prime} \mathrm{S}$, $152^{\circ} 49^{\prime} \mathrm{E}$, on bark of isolated rainforest tree, R.W. Rogers 7613, 8 Jun 1983; holotype BRI 687091.

Thallus off-white to pale fawn, surface smooth and shiny, corticolous; apothecia lirelline, numerous, conspicuous, raised, irregularly branched, 2-4 $\mathrm{mm}$ long, $0.1 \mathrm{~mm}$ wide, lips closed, with a conspicuous thalline margin; proper exciple completely, or almost completely, carbonised; hymenium inspersed, I-ve; ascospores elongate ellipsoid, hyaline, 50-70(-90) $\mu \mathrm{m}$ long, 10-12 $\mu \mathrm{m}$ wide, 9-14(-16)-locular, I+ blue.

Chemistry: stictic acid.

Specimens examined: New South Wales: North Coast: Cherrytree State Forest, Mallanganee, $30 \mathrm{~km}$ WSW of Casino, 28 $8^{\circ} 4^{\prime}$ S, $152^{\circ} 43^{\prime}$ E, A.W. Archer G 575, 13 Nov 2000 (NSW 741791). Northern Tablelands: Dorrigo National Park, track to Crystal Shower Falls, $30^{\circ} 23^{\prime} \mathrm{S}, 152^{\circ} 44^{\prime} \mathrm{E}$, alt. c. $700 \mathrm{~m}$, A.W. Archer G 536, 2 Nov 2000 (NSW 741792).

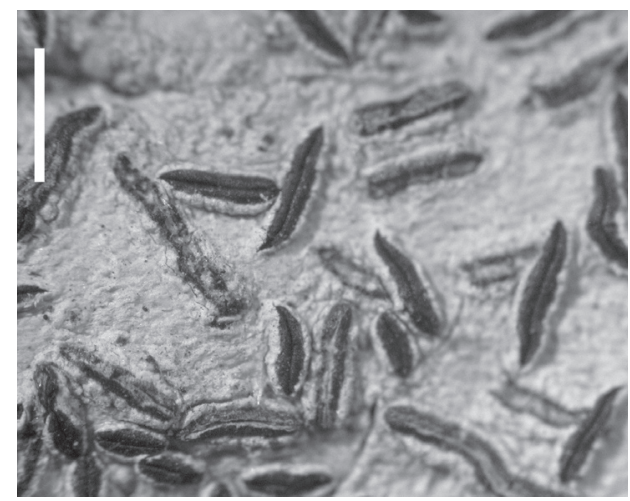

Fig. 3. Graphis eimeoensis, holotype. Scale bar $=1 \mathrm{~mm}$

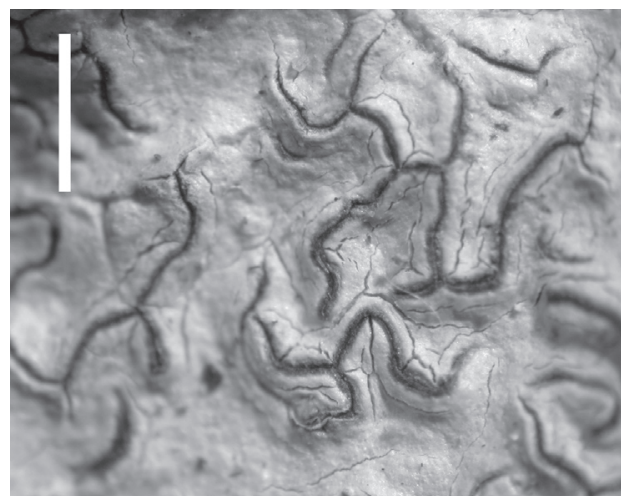

Fig. 4. Graphis gloriosensis, holotype. Scale bar $=1 \mathrm{~mm}$ 
Graphis gloriosensis is characterised by the conspicuous branched lirellae, the completely, or almost completely, carbonised exciple, the inspersed hymenium and the presence of stictic acid. It resembles the chemically similar Graphis rustica Kremp. but that species has simple lirellae and a non-inspersed hymenium ["purum" fide Redinger 1936)]. Graphis gloriosensis is distinct from the chemically similar G. crassilabra Müll. Arg. (Müller 1882) which has a non-inspersed hymenium and immersed lirellae, and from the recently described Indian species Graphis longissimea Makhija \& Adawadkar (Makhija \& Adawadkar 2005) which has a distinctly crenate exciple, an inconspicuous thalline margin, longer lirellae (up to $20 \mathrm{~mm}$ long) and a non-inspersed hymenium (U. Makhija in litt. 2006). Graphis superans Müll.Arg. (Müller 1894) also resembles the new species in lirellae morphology and hymenium inspersion but has larger ascospores and lacks lichen compounds.

The new species is reported from Queensland and New South Wales.

The spelling of the epithet gloriosensis has been chosen deliberately; it is made up of glorios-, derived from Mount Glorious, the type location and the Latin suffix -ensis, place of origin.

\section{New reports}

Diorygma hololeucum (Mont.) Kalb, Staiger \& Elix, Symb. Bot. Ups.

34: 155 (2004)

Fig. 5

= Graphis hololeuca Mont., in Junghuhn, Plantae junghuhnianae Fasc. IV: 473 (1855)

= Graphina hololeuca (Mont.) Müll.Arg., Flora 65: 386 (1882)

Type: Java [Indonesia] s. loc., Junghuhn ex herb. Buse; lectotype: L (fide Kalb, Staiger \& Elix 2004).

Thallus off-white to pale greenish white, surface smooth and slightly shiny, corticolous; apothecia lirelline, white, conspicuous, numerous, sessile, straight, curved or sinuous, sometimes branched, 2-8 $\mathrm{mm}$ long, $0.5-1 \mathrm{~mm}$ wide, lips open; proper exciple uncarbonised; disc smooth white pruinose, revealing the black epithecium when abraded; hymenium not inspersed, weak I+ blue at margins; ascospores ellipsoid, hyaline, muriform, 130-160 $\mu \mathrm{m}$ long, 30-36 $\mu \mathrm{m}$ wide, I+ blue.

Chemistry: protocetraric acid

Specimens examined: Queensland: Mossman-Mt Molloy Road, $1 \mathrm{~km} \mathrm{~S}$ of Lions Lookout, $20 \mathrm{~km} \mathrm{~N}$ of Mt Molloy, $16^{\circ} 32^{\prime} \mathrm{S}, 145^{\circ} 23^{\prime} \mathrm{E}$, alt. c. $390 \mathrm{~m}$, on canopy of road side tree, Elix 36875, 36888, 36895, 36898, 4 Aug 2006 (CANB).

The species is characterised by the conspicuous, white, sessile open lirella and thus differs from the other Australian Diorygma species with protocetraric acid, D. pruinosum, which has immersed, inconspicuous lirellae.

Diorygma hololeucum has previously been reported from the Philippines, Papua New Guinea, Malaysia and Indonesia (Kalb, Staiger \& Elix 2004) and the specimens cited above represent the most southerly locality currently known. The specimens were collected from the canopies of recently felled trees; if tree canopies are the preferred habitat in Australia it may explain why this conspicuous species has not been collected before. 
Graphis atrofusca (Müll.Arg.) Stizen., Ber. Tät. St. Gallisch naturw.

Gesellsch. 1889-1890: 186 (1891)

Fig. 6

= Graphina atrofusca Müll.Arg., Flora 70: 74 (1887)

Type: South Africa, Transvaal, Lydenburg, Wilms 46 \& 70; syntypes: G.

Thallus off-white to pale greenish white, surface uneven, rough, dull, corticolous; apothecia lirelline, numerous, conspicuous, scattered, simple, straight, curved or sinuous, rarely branched, $1-2(-3) \mathrm{mm}$ long, $0.1-0.25 \mathrm{~mm}$ wide, lips open; exciple completely carbonised, thin at the base; disc reddish brown pruinose; hymenium not inspersed, I-ve; ascospores ellipsoid, hyaline, muriform, 30-36 $\mu \mathrm{m}$ long, 16-20 $\mu \mathrm{m}$ wide, $8-10$ x 2-5-locular, I+ blue.

Chemistry: no lichen compounds found.

Specimens examined: Queensland: Keppel Sands, Fitzroy Estuary, $23^{\circ} 19^{\prime} \mathrm{S}, 150^{\circ} 47^{\prime} \mathrm{E}$, sea-level, on Excoecaria, Rogers 775, 10 Jun 1975 (BRI 687037); Boydong Island, $11^{\circ} 29^{\prime} \mathrm{S}, 143^{\circ} 02^{\prime} \mathrm{E}$, on Pemphis acidula, Youman s.n., 17 Jul 1975 (BRI 686972 p.p.).

Graphis atrofusca is characterised by the open lirellae, the completely carbonised exciple, the muriform ascospores and the absence of lichen compounds. It resembles Graphis semi-aperta Müll.Arg. but that species has septate ascospores, an inspersed hymenium and contains norstictic acid.

Graphis geraensis Redinger, Ark. Bot. 27A(3): 12 (1935)

Fig. 7

Type: Brazil, Minas Geraës, São João d'el Rey, G. Malme 320, 1 Sep 1892); holotype: S.

Thallus pale olive-green to pale fawn, surface smooth and dull, corticolous; apothecia lirelliform, thin, black, numerous, conspicuous, initially simple, becoming much branched, sessile, lips closed, $1-5 \mathrm{~mm}$ long, $0.15-0.25 \mathrm{~mm}$ thick; proper exciple completely carbonised; hymenium 90-120 $\mu \mathrm{m}$ tall, not inspersed, I-ve; ascospores 8 per ascus, elongate-ellipsoid, hyaline, 30-40 $\mu \mathrm{m}$ long, 5-8 $\mu \mathrm{m}$ wide, $8-10$-locular, I+ve blue.

Chemistry: no lichen compounds found.

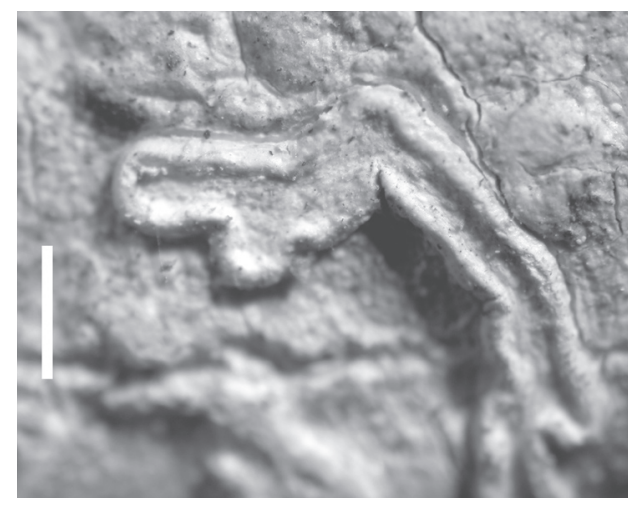

Fig. 5. Diorygma hololeucum, Elix 36898. Scale bar $=1 \mathrm{~mm}$

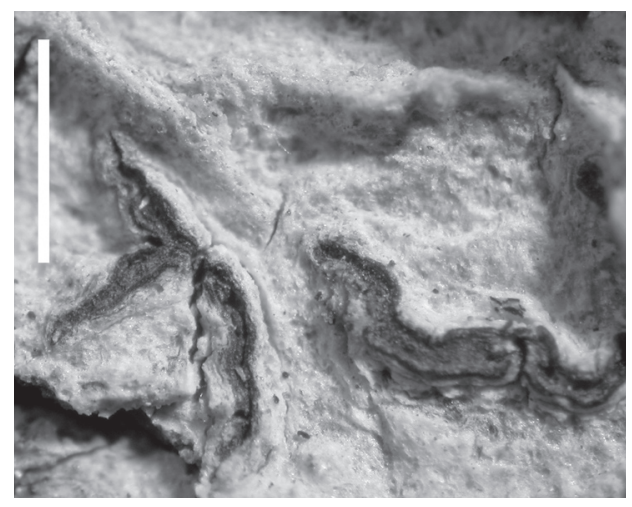

Fig. 6. Graphis atrofusca, Rogers 775.

Scale bar $=1 \mathrm{~mm}$ 
Graphis geraensis is characterised by the conspicuous, much branched lirellae, the completely carbonised exciple, the non-inspersed hymenium and the absence of lichen compounds. The ascospores in the holotype were reported to be 4-locular and $15 \mu \mathrm{m}$ long but these were obviously immature ascospores as the carbonised exciple places the species in Graphis, rather than Fissurina (Lücking, in litt.); in all other respects the Australian specimens agree with the protologue. The species resembles Graphis intricata Fée but that species has smaller ascospores (15-26 $\mu \mathrm{m}$ long) and contains norstictic acid.

The species occurs in eastern Australia, in Queensland and New South Wales, and is also found in Brazil.

Specimens examined: Queensland: Numinbah State Forest picnic area, by side of Nerang River, $28^{\circ} 07^{\prime} \mathrm{S}, 153^{\circ} 15^{\prime} \mathrm{E}$, c. $20 \mathrm{~km} \mathrm{~W}$ of Burleigh Heads, Archer G 713, 23 Oct 2001 (NSW 741796).

New South Wales: Northern Tablelands: Dorrigo National Park, Wonga Walk, on upper branches of fallen tree, in subtropical rainforest, $30^{\circ} 22^{\prime} 45^{\prime \prime S}, 152^{\circ} 44^{\prime} 00^{\prime \prime} \mathrm{E}$, alt. $700 \mathrm{~m}$, Archer G 742, 25 Oct 2005 (NSW 741794); west side of Never Never Creek, c. $9 \mathrm{~km} \mathrm{~N}$ of Bellingen, 30²1'S, 152 ${ }^{\circ} 54^{\prime} \mathrm{E}$, alt. 65 m, Archer G 822, 23 Oct 2005 (NSW 741793). Southern Tablelands: Monga National Park, Penance Grove, $28 \mathrm{~km}$ SE of Braidwood, 35³5'58"S, 14954'51"E, alt. 655 m, Elix 37028, 1 Mar 2005 (CANB).

Graphis illota Müll.Arg., Hedwigia 34: 32 (1895)

Fig. 8

Type: Brazil, Santa Catherina Province, Ule no. 273; holotype: G: isotype: MICH.

Thallus off-white to pale fawn, surface smooth and dull, corticolous; apothecia lirelline, lirellae conspicuous, scattered, sessile with a complete thalline margin and thin thalline coating on the exposed exciple, sulcate, simple, straight, curved or sinuous, rarely branched, 1-2.5 mm long, $0.3-0.5 \mathrm{~mm}$ wide; exciple completely carbonised, lips closed; hymenium not inspersed, I-ve; ascospores elongate ellipsoid, hyaline, (72-)80-100 $\mu \mathrm{m}$ long, 8-12 $\mu \mathrm{m}$ wide, 16-20-locular, I+ blue.

Chemistry: no lichen compounds found.

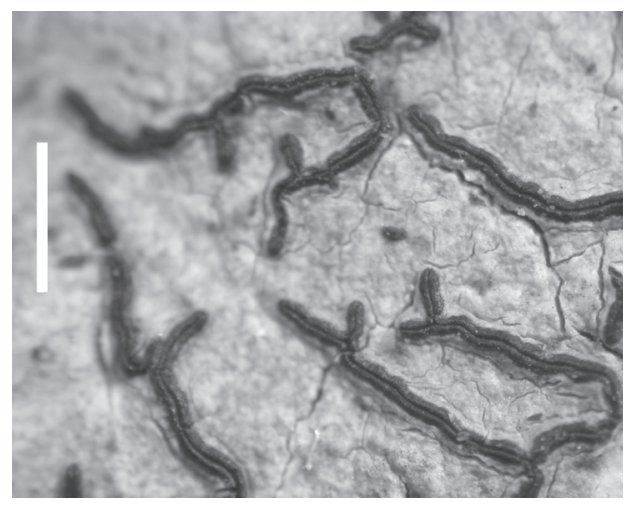

Fig. 7. Graphis geraensis, Elix 37028. Scale bar $=1 \mathrm{~mm}$

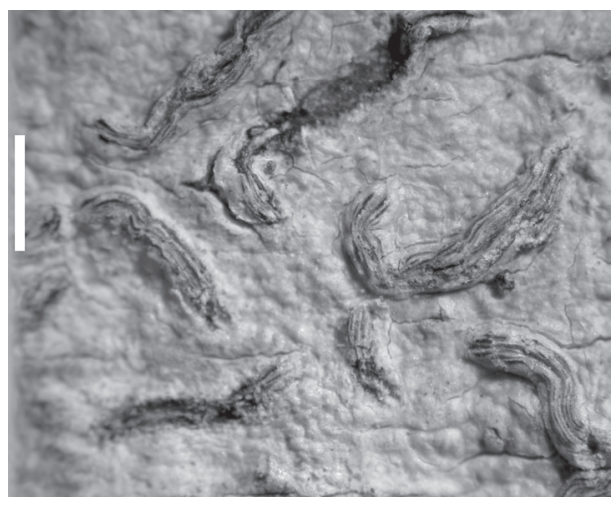

Fig. 8. Graphis illota, Rogers 8478 .

Scale bar $=1 \mathrm{~mm}$ 
Specimen examined: Queensland: Mount Glorious, $27^{\circ} 18^{\prime} \mathrm{S}, 152^{\circ} 43^{\prime} \mathrm{E}$, alt. c. $600 \mathrm{~m}$, on tree in rainforest, Rogers 8478, 31 Jul 1986 (BRI 687028).

The specimen is characterised by conspicuous lirellae with a thalline coating, the large ascospores and the absence of lichen compounds and is tentatively here identified as Graphis illota Müll.Arg. The species somewhat resembles G. flexibilis Kremp. but both of these taxa are part of a difficult complex and the identification may need to be changed as new information becomes available.

The species also occurs in Brazil and is reported from India (Awasthi 1991).

Graphis macella Kremp., Flora 59: 380 (1876)

Fig. 9

= Graphina macella (Kremp.) Müll.Arg., Flora 63: 23 (1880)

Type: Brazil, “ad ramulos Villosiae”, Glaziou 6289b; holotype: M.

Thallus off-white, surface smooth and somewhat shiny, corticolous; apothecia lirelline, numerous, semi-immersed to sessile, simple, straight, curved or sinuous, rarely branched, striate, the grooves filled with white thalline material, 1-3(-4) mm long, $0.2-0.5 \mathrm{~mm}$ wide; exciple laterally, to almost completely, carbonised; hymenium not inspersed, I-ve; ascospores 1 per ascus, ellipsoid, hyaline, muriform, 94-130 $\mu \mathrm{m}$ long, 25-32 $\mu \mathrm{m}$ wide, I+ blue.

Chemistry: no lichen compound found

Specimen examined: Queensland: Mount Glorious, $27^{\circ} 20^{\prime} \mathrm{S}, 152^{\circ} 46^{\prime} \mathrm{E}$, on dead rainforest tree, Stevens 3182, 9 Apr 1975 (BRI 686890).

The species is characterised by the striate lirellae, the laterally carbonised exciple, the muriform ascospores and the absence of lichen compounds; it is distinguished from the somewhat similar G. longula Kremp. by the muriform ascospores.

The species is also reported from Kenya (Staiger 2002).

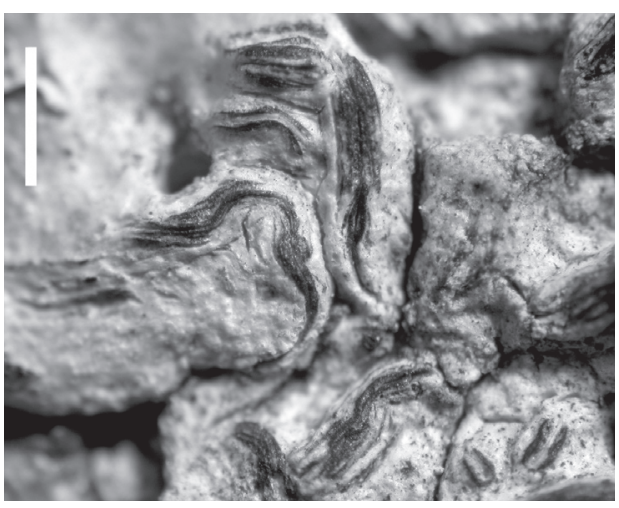

Fig. 9. Graphis macella, Stevens 3182. Scale bar $=1 \mathrm{~mm}$

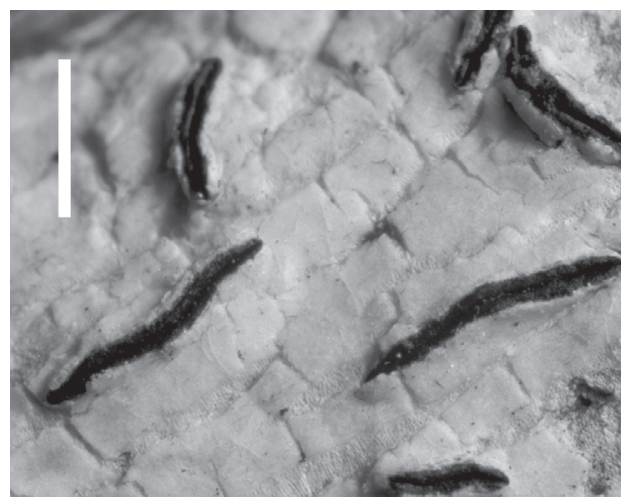

Fig. 10. Graphis maritima, BRI 686970. Scale bar $=1 \mathrm{~mm}$ 
Graphis maritima (A.W.Archer) A.W.Archer, Systematics and Biodiversity

5: 16 (2007)

Fig. 10

= Graphina maritima A.W.Archer, Mycotaxon 89: 322 (2004)

Type: Solomon Islands: Makira Province, San Cristobal Island, on trees along the beach, D.J. Hill 9821, 15.viii.1965; holotype: BM.

Thallus off-white, thin, surface smooth and dull, corticolous; apothecia lirelline, conspicuous, black, numerous, scattered, simple, straight, curved or sinuous, 1-3 mm long, $0.15-0.3 \mathrm{~mm}$ wide, lips closed, with a conspicuous thalline margin, terminally acute; exciple completely carbonised; hymenium not inspersed, I-ve; ascospores narrow-ellipsoid, hyaline, muriform, 8 per ascus, $28-38 \mu \mathrm{m}$ long, $10-12 \mu \mathrm{m}$ wide, $8-10$ x 2-4-locular, I+ blue.

Chemistry: no compounds found.

Specimen examined: Queensland: Boydong Island, $11^{\circ} 29$ S, $143^{\circ} 01 \mathrm{E}$, on Salacia chinensis, Youman s.n., 17 Jul 1985; (BRI 686970).

The species is characterised by the completely carbonised exciple, the muriform ascospores, the non-inspersed hymenium and the absence of lichen compounds. It was previously known only from the Solomon Islands but is now reported from northern Queensland. The species resembles Graphis platycarpa Eschw. but is distinguished from that species by the completely carbonised exciple and the smaller ascospores. Superficially, the species resembles G. geraensis but differs in the muriform ascospores.

Graphis tenellula Vain., Ann. Acad. Sci. Fenn., Ser. A, (6)7: 160 (1915)

Fig. 11

Type: Dominican Republic, La Cumbra, C. Raunkiaer 490 p.p., 9 Apr 1906; holotype: TUR-V 27701.

= Graphis guimarana Vain., Ann. Acad. Sci. Fenn., Ser. A,15, 6: 248 (1920). Type: The Philippines, Guimaras, E.D. Merrill 6716 p.p., Mar 1910; holotype: TUR-V 27811.

Thallus off-white to pale fawn, surface smooth and dull, corticolous; apothecia lirelline, numerous, scattered, simple, straight, curved or sinuous, sessile, with a conspicuous thalline margin, $0.5-2 \mathrm{~mm}$ long, $0.1-0.2 \mathrm{~mm}$ wide, lips closed, rarely slightly open; exciple laterally carbonised, conspicuously open at the base; hymenium inspersed, I-ve; ascospores 8 per ascus, elongate ellipsoid, hyaline, 30-40 $\mu \mathrm{m}$ long, 7-10 $\mu \mathrm{m}$ wide, 8-12-locular, I+ blue.

Chemistry: norstictic acid.

Specimens examined: Northern Territory: Howard Springs, $30 \mathrm{~km} \mathrm{~S} \mathrm{of} \mathrm{Darwin,} \mathrm{Stevens} \mathrm{s.n.,}$ 14 Jul 1981 (BRI 686941); Nudgee, Nudgee road, on Poinciana, Beasley 4049, 13 May 1975 (BRI 686906). Queensland: Dan Dan Scrub, on Flutter Creek, $24.5 \mathrm{~km} \mathrm{~S}$ of Calliope, $24^{\circ} 12^{\prime} \mathrm{S}$, $151^{\circ} 04^{\prime}$ E, alt. c. $150 \mathrm{~m}$, in dry rainforest, Rogers 8092, 3 Sep 1985 (BRI 687048). New South Wales: North Coast: Broken Head, c. 8 km S of Byron Bay, $28^{\circ} 42^{\prime}$ S, $153^{\circ} 37^{\prime} \mathrm{E}$, alt. c. $100 \mathrm{~m}$, Archer G 283, 5 Nov 1998 (NSW 740923); South Ballina, S bank of Richmond River, 2853'S, 153³1'E, alt. c. 5 m, Archer G 286, 2 Nov 1998 (NSW 740922); 6 km NNW of Bellingen, on tree by side of un-named creek at end of Adams Lane, 30²2'20"S, 152 52'E, alt. c. $100 \mathrm{~m}$, Archer G 743, 27 Oct 2005 (NSW 740916); Cherrytree State Forest, Mallanganee, $28^{\circ} 54^{\prime} \mathrm{S}, 152^{\circ} 43^{\prime} \mathrm{E}, \mathrm{c} .80 \mathrm{~km}$ ENE of Tenterfield, Archer G 320, 1 Nov 1998 (NSW 742765). 
Graphis tenellula is characterised by the simple lirellae, the laterally carbonised exciple, the inspersed hymenium and the presence of norstictic acid. The species resembles Graphis librata C.Knight and the two species were reported as conspecific (Wirth and Hale 1978); however, the ascospores are larger in G. tenellula $[15-25(-30) \mu \mathrm{m}$ long in $G$. librata] and the hymenium is not inspersed in the latter species. This is the first report of the species in Australia but it is possible that it has previously been misidentified as G. librata C. Knight or G. desquamescens (Fée) Zahlbr.

The species occurs in the West Indies, the Philippines and in north and north-eastern Australia and was reported from India, as G. guimarana Vain. (Patwardhan \& Kulkarni 1976).

Phaeographis epruinosa (Redinger) Staiger, Bibliotheca Lichenologica

85: 323 (2002)

Fig. 12

= Phaeographina epruinosa Redinger, Ark. Bot. 26A(1): 81 (1933

Type: Brazil, Matto Grosso, Coxipó Mirim, G.A. Malme 3662, 1 Jun 1984; holotype: $\mathrm{S}$.

Thallus off-white to pale fawn, surface smooth and shiny, corticolous; apothecia lirelline, numerous, conspicuous, sessile, open with a conspicuous thalline margin, straight, curved or sinuous, sometimes irregularly branched, 1-4 mm long, 0.3-0.5 mm wide; proper exciple thin, laterally dark, absent below; epithecium matt black; hymenium 120-140 $\mu \mathrm{m}$ tall, not inspersed, I-ve; ascospores ellipsoid, pale brown, muriform, 30-40 $\mu \mathrm{m}$ long, 10-12 $\mu \mathrm{m}$ wide, 6-8 x 1-3-locular, I+ red brown.

Chemistry: stictic acid (major), constictic acid (minor), cryptostictic acid (trace) and menegazziaic acid (trace).

Specimen examined: Queensland: Tully Gorge, 49 km NW of Tully, 17²4'20"S, 147³7'39"E, alt. $145 \mathrm{~m}$, on trunk of fallen tree, margins of rainforest, Elix 36979, 36985, 28 Jul 2006 (CANB).

Phaeographis epruinosa is characterised by the sessile, open lirellae, the uninspersed hymenium, the small, pale brown, muriform ascospores and the presence of stictic acid. Traces of stictic acid were reported in the holotype by Nakanishi (in sched.).

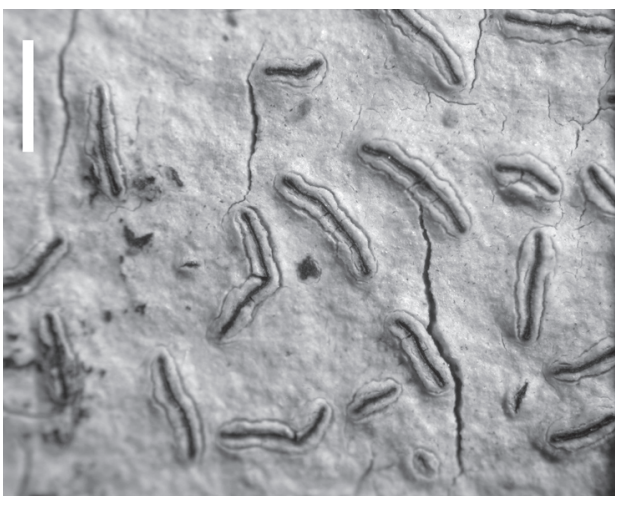

Fig. 11. Graphis tenellula, Archer G 283. Scale bar $=1 \mathrm{~mm}$

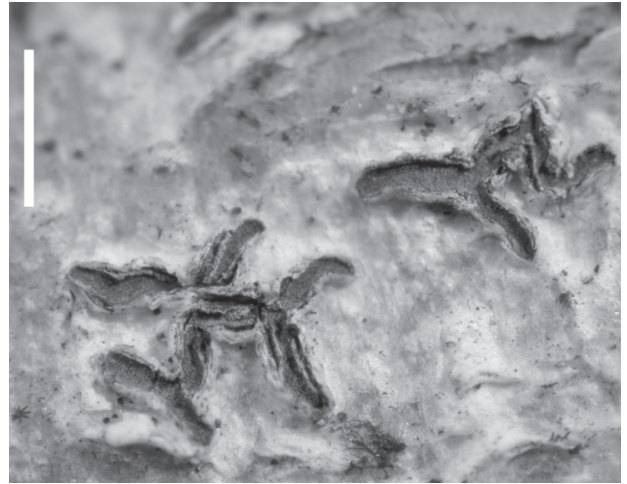

Fig. 12. Phaeographis epruinosa, Elix 36979. Scale bar $=1 \mathrm{~mm}$ 
Two additional species have similar ascospores and contain stictic acid viz: Phaeographina torquescens (Nyl.) Redinger (Redinger 1936), and Phaeographis montiscalvi (A.W.Archer) A.W.Archer (Archer 2006) but these species are distinguished from $P$. epruinosa by the carbonised exciple and inspersed hymenium, and the closed lirellae respectively.

The species is so far known only from two specimens in Australia and also occurs in Brazil (fide supra).

Platygramme platyloma (Müll.Arg.) M.Nakan. \& Kashiw., Bull. Natn. Sci. Mus. Tokyo, Ser.B 29: 89 (2003)

Fig. 13

= Phaeographina platyloma Müll.Arg., Flora 65: 398 (1882)

= Phaeographina pudica (Mont. \& Bosch) Zahlbr. var. platyloma (Müll.Arg.) Redinger Rev. Bryol. Lichénol. 9:97 (1936)

Type: Java [Indonesia], 119a; lectotype: L (fide Nakanishi).

Thallus pale fawn to pale reddish brown, surface smooth and shiny, corticolous; apothecia lirelline, inconspicuous, scattered, sessile, straight, curved or sinuous, sometimes branched, slips slightly open, revealing a black disc, 2-6 mm long, 0.3-0.5 $\mathrm{mm}$ wide; exciple conspicuously apically carbonised; hymenium inspersed; ascospores 1 per ascus, elongate ellipsoid, pale brown, muriform, 80-100 $\mu \mathrm{m}$ long, 24-30 $\mu \mathrm{m}$ wide.

Chemistry: no lichen compounds found

Specimen examined: Queensland: Mossman-Mt Molloy Road, $1 \mathrm{~km} \mathrm{~S}$ of Lions Lookout, $20 \mathrm{~km} \mathrm{~N}$ of Mt Molloy, $16^{\circ} 32^{\prime} \mathrm{S}, 145^{\circ} 23^{\prime}$ E, alt. c. $390 \mathrm{~m}$, on canopy of road side tree, Elix 36896, 4 Aug 2006 (CANB).

The species is characterised by the apically carbonised exciple, the pale brown, muriform ascospores and the absence of lichen compounds. It resembles $P$. impudica (A.W.Archer) A.W.Archer but is distinguished from that species by the smaller ascospores, 80-100 $\mu \mathrm{m}$ long as compared to $135-180 \mu \mathrm{m}$ long in P. impudica. It is distinguished from the somewhat similar species P. pudica (Mont. \& Bosch) M.Nakan. \& Kashiw. by the larger

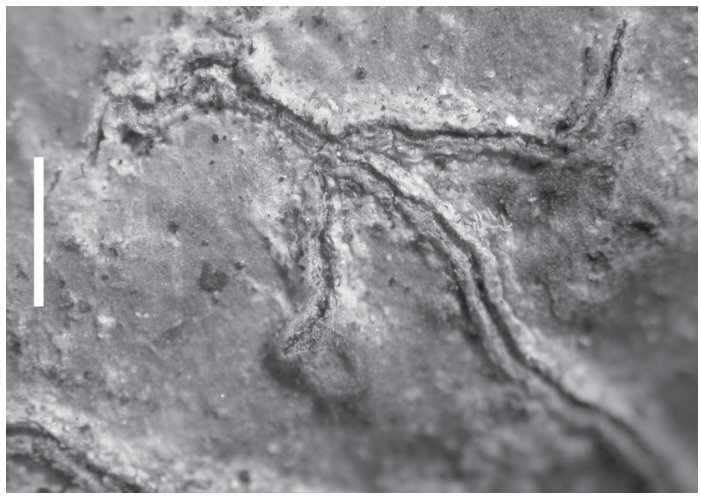

Fig. 13. Platygramme platyloma, Elix 36896.

Scale bar $=1 \mathrm{~mm}$ 
ascospores (160-200 $\mu \mathrm{m}$ long), the concealed carbonised exciple and the presence of echinocarpic acid in that species.

Platygramme platyloma also occurs in Japan and Indonesia.

\section{Acknowledgments}

The authors are grateful to Dr. Robert Lücking, Department of Botany, The Field Museum of Natural History, Chicago, for the provision of information on, and illustrations of, several type specimens.

\section{References}

Archer AW (2006) The lichen family Graphidaceae in Australia. Bibliotheca Lichenologica 94: $1-191$.

Archer AW (2007) Key and checklist for the lichen family Graphidaceae (lichenised Ascomycota) in the Solomon Islands. Systematics and Biodiversity 5: 9-22.

Awasthi DD (1991) A key to the microlichens of India, Nepal and Sri Lanka. Bibliotheca Lichenologica 40: 1-337.

Elix JA \& Ernst-Russell KD (1993) A catalogue of standardised thin layer chromatographic data and biosynthetic relationships for lichen substances, 2nd. edn. (Australian National University: Canberra)

Elix JA, Kalb K \& Wardlaw JH (2003) Neotricone and norperistictic acid, two new depsidones from the lichen genus Phaeographis. Australian Journal of Chemistry 56: 315-317.

Hue AM (1891) Lichenes exoticos. Nouvelles Archives du Muséum d'Histoire Naturelle de Paris, sér. 3, 3: 33-192.

Kalb K, Staiger B \& Elix JA (2004) A monograph of the lichen genus Diorygma-a first attempt. Symbolae Botanicae Upsalienses 34: 133-181.

Makhija U, Kekre S \& Patwardhan PG (1992) Materials for a lichen flora of the Andaman Islands: VII-The family Graphidaceae. Biovigyanam 18: 12-20.

Makhija U \& Adawadkar B (2005) Some new species of Graphis (Lichenised Ascomycota) from the Andaman and Nicobar Islands of India. Mycotaxon 91: 369-379.

Makhija U \& Adawadkar B (2007) Trans-septate species of Acanthothecis and Fissurina from India. Lichenologist 39: 165-185.

Müller J (1882) Lichenologisches Beiträge XVI. Flora 65: 499-505.

Müller J (1888) Lichenes Paraguayenses. Revue Mycologique 38: 1-32.

Müller J (1894) Lichenes usambarenses. Botanischer Jahrbücher für Systematik, Pflanzengeschichte und Pflanzengeographie 20: 238-298.

Patwardhan PG \& Kulkarni CR (1976). Some additions to the lichen flora of India IV: Graphis and Graphina (Family Graphidaceae). Biovigyanam 2: 123-1232.

Redinger KM (1936) Die Graphideen der Sunda-Inseln. Revue Bryologique et Lichénologique 9: $31-122$.

Staiger B (2002) Die Flechtenfamilie Graphidaceae. Bibliotheca Lichenologica 85: 1-526.

Vainio EA (1899) Lichenes novi rarioresque. Hedwigia 38: 253-259.

Wirth M \& Hale ME (1978) Morden-Smithsonian expedition to Dominica: The Lichens (Graphidaceae). Smithsonian Contributions to Botany 40: 1-64.

Zahlbruckner A (1908) Die Flechten der Samoa-Inseln, in Rechinger K, Botanische und zoologische Ergebnisse, Denkschriften der Kaiserlichen Akademie der Wissenschaften Wien, Mathematisch-Naturwissenschaftliche Klasse 81: 222-287. 